\title{
ROZHLASOVÁ HUDBA A PAVEL HAAS ${ }^{1}$
}

K rozhlasu a jeho překotnému rozvoji od poloviny 20. let 20. století se váže vznik Haasovy Předehry pro rozhlas, op. 11 z let 1930-1931. Toto dílo je nanejvýš příznačným dobovým svědectvím rozvoje nového masového média, podmínek a stavu dobové hudebně interpretační praxe $\mathrm{v}$ rozhlasových studiích na přelomu 20. a 30. let a tehdy nově vznikajících tzv. radiogenních uměleckých forem. Haasovu Předehru je proto třeba nahlížet a zkoumat zejména v kontextu tehdejších estetických měřítek rozhlasové tvorby a v kontextu specifických technických podmínek, $\mathrm{v}$ nichž byla rozhlasová díla provozována a jimž se přizpůsobovaly také skladatelovy umělecké vyjadřovací prostředky.

\section{K počátkům hudebního rozhlasu}

Vynález rozhlasu a jeho rozšíření do podoby masového komunikačního prostředku, které proběhlo závratnou rychlostí ve 20. a 30. letech, nemohlo nezanechat otisk v tehdejší kultuře a umění. Přenos zvuku na dálku pomocí elektromagnetického vlnění a jeho „vyvoláváni““ pomocí krystalu či lampy v elektrických dřevěných skříňkách vybavených reproduktorem dokázalo okouzlit širokou škálu tehdejších obyvatel Evropy a Ameriky od nadšených radioamatérů po prosté pasivní posluchače, žádající aktuální informace či hledající pouhý oddech a zábavu. Rádio fascinovalo. Již na počátku 20. let byly v hospodářsky nejvyspělejších zemích tehdejšího světa odhaleny široké možnosti využití tohoto nového sdělovacího média ve službě veřejnosti. V prvopočátcích se názory na zužitkování rozhlasu přirozeně lišily, postupně se však prosadila především funkce zpravodajská a informační, výchovně vzdělávací, osvětová, komerční či rekreační. Nutno zdůraznit, že od počátku hrálo v rozhlasovém vysílání velmi podstatnou

1 Předložená práce vznikla za finanční podpory Ministerstva kultury v rámci institucionálního financování na dlouhodobý koncepční rozvoj výzkumné organizace Moravské zemské muzeum (DKRVO, MK000094862).

2 Komerční vysílací stanice se rozšiřǐly zvláště v USA. V Evropě došlo ke komercionalizaci rozhlasu teprve $\mathrm{v} 70$. letech 20 . století. 
úlohu umění - přednes literárních děl, dramatická tvorba a zejména hudba. Ta stála prakticky již u kolébky pokusů s rádiovým přenosem zvuku³ a hudební produkce naplňovala rovněž valnou část programu nově institucionalizovaných evropských i amerických rozhlasových stanic. Jemná diferenciovanost hudby byla mimo jiné skvělým prostředkem pro ověření kvality přenášeného zvuku.

Po vzniku prvních stálých rozhlasových stanic v USA $(K D K A, 1920)$ a Velké Británii (British Broadcasting Company, 1922) zahajuje jako jeden z prvních států rozhlasové vysílání také Československo. Součástí prvního rozhlasového ateliéru sídlícího v zapůjčeném sokolském stanu na kopci nad Prahou ve Kbelích, z něhož se od 18. května 1923 ozývalo pravidelné každodenní vysílání, bylo i pianino. Na něj byly provozovány hudební a pěvecké produkce, jež byly jednou z položek krátkého hodinového večerního vysílacího programu vedle zpráv burzovních, meteorologických a sportovních. ${ }^{4}$ Rozhlas se v prvých letech své činnosti musel potýkat se značnými technickými nedostatky ovlivňujícími kvalitu přijímaného zvuku. Ty byly dány zejména nedokonalostí tehdejšího technického vybavení. Živé hudební přenosy ze studia tak byly často oříškem jak pro zvukové techniky, tak pro samotné rozhlasové interprety. Kbelská vysílací stanice, která mezitím z provizorního stanu přesídlila do malého dřevěného domku, disponovala na počátku roku 1924 pouze miniaturním studiem a byla vybavena jedním uhlíkovým mikrofonem, který byl schopen kvalitně snímat jen malá instrumentální tělesa. O této situaci informoval v lednu 1924 na svých stránkách věstník Radiojournalu: „Je-li kvartet složen jen ze smyčcových nástrojů a piana, je bezdrátový přenos velmi dobrý. Jakmile však obsahuje kvartet nebo kvintet mimo strunné nástroje ještě flétnu, ukazuji se pravidelně tytéž nepřijemné úkazy zvukové interference a tím zpưsobené pazvuky. U nás nelze zatím na jeden večer pozvati více než dva nebo tři umělce, poněvadž misto nestačí. "“ Této situaci a úsilí, aby zvuk z rádiových přijímačů zněl pokud možno věrně a co nejméně zkresleně, byl přizpůsobován i výběr hudebních nástrojů a jejich vzájemné kombinace, sestavy na tehdejší dobu většinou dosti netradiční. Známé hudební kusy tak zněly např. $\mathrm{v}$ triových úpravách pro violoncello, klarinet a klavír či kornet, flétnu a klavír.

V těchto primitivních poměrech se 12 . února 1925 uskutečnil první rozhlasový přenos opery z Národního divadla v Praze. Do éteru byly přenášeny Smetanovy Dvě vdovy. Zvuk z jeviště byl snímán jedním mikrofonem, jenž byl umístěn vedle nápovědy. Tímto způsobem ještě vůbec nebylo možno zachytit celé zvukové spektrum orchestrálního zvuku, ani obsáhnout celý akustický prostor jeviště. O pár měsíců později 15 . května 1925 byl realizován první přenos koncertu České filharmonie ze Smetanovy síně Obecního domu v Praze u příležitosti zahájení festivalu Mezinárodní společnosti pro soudobou hudby. Zde se rozhlasoví techni-

3 Už roku 1910 byl z Metropolitní opery v New Yorku bezdrátově přenášen hlas tenoristy Enrica Carusa v Mascagniho opeře Cavallleria rusticana. Radiojournalu, Čsl. zpravodajství radiotelefonického, 1935, s. 23. 
ci museli potýkat s podobnými problémy, jaké je provázely v Národním divadle. Požadavek organizátorů koncertu, že mikrofon nesmí být postaven na viditelném místě, aby nerušil estetický vzhled Smetanovy síně a dojem diváků z koncertu, nedovolil umístit př́stroj do akusticky výhodné pozice. Velký orchestrální aparát a bohaté polyfonní předivo hlasů se často slévalo v nežretelný chumel tónů. Rozhlas se tehdy mohl jen velmi vzdáleně přiblížit zvukovému dojmu a zážitku, který si odnášeli reální posluchači koncertu. Ke zkvalitnění rozhlasových hudebních přenosů dochází až na počátku 30. let, kdy se zdokonaluje amplifikační zařízení a do divadelních a koncertních prostor je již možno umístit vícero mikrofonů. Kontrolu a spojování mikrofonů zajištoval z viditelného místa (např. divadelní lóže) operatér, nadto vznikla pozice zvukového režiséra, který poskytoval zpětnou vazbu týkající se výsledného zvuku z reproduktorů.

Úsilí rozhlasu o co nejplastičtější zachycení hudební reprodukce přivádí organizátory rozhlasových stanic ke snaze nalézt vhodné prostory $\mathrm{k}$ vytvoření velkých hudebních studií, která by vyhovovala $\mathrm{z}$ akustických hledisek a umožnila věrné zachycení orchestrálního zvuku. V celé Evropě se za tímto účelem budují nová rozhlasová studia a také československý Radiojournal v Praze získává roku 1927 pro své koncerty velký sál Národního domu na Vinohradech. S tímto trendem souvisel i vznik rozhlasových hudebních těles. V Německu se jako první etabloval 6. ledna 1923 rozhlasový orchestr v Lipsku a nedlouho po něm 18. června 1925 také Berlínský rozhlasový orchestr (Berliner Funk-Orchester), jenž v prvním roce své činnosti dosáhl počtu 64 hráčů. V britském BBC začínal roku 1924 orchestr o 18 členech, který se však po své institucionalizaci coby BBC Symphony Orchestra roku 1930 rozšíril až do obřího počtu 114 instrumentalistů. V českých poměrech byl vznik rozhlasových orchestrálních těles pozvolnější. Jejich základem se stala malá komorní uskupení rozšiřovaná podle potřeby a postupem času o další hráče. V Praze byl roku 1925 vytvořen ansámbl dvou houslí, violoncella, klavíru, harmonia a hoboje. Již roku 1926 ovšem vedení stanice přistoupilo k založení rozhlasového orchestru, jenž čítal 19 hráčủ. Je samozřejmé, že pro své koncerty muselo být těleso ještě doplňováno některými hráči orchestru České filharmonie. Když se roku 1928 ujímal funkce šéfdirigenta rozhlasového orchestru Otakar Jeremiáš, byl soubor 24členný a působil v obsazení: 5 prvních a 3 druhé housle, 2 violy, 2 violoncella, kontrabas, flétna, hoboj, 2 klarinety, fagot, 2 lesní rohy, 2 trubky, pozoun, timpány. Po doplnění výpomocemi z České filharmonie čítal v úhrnu 52 hráčů. ${ }^{6}$

\section{Situace v brněnském rozhlase}

Poněkud jiná situace panovala $v$ Brně. Počátky brněnské rozhlasové stanice sahají do roku 1924, kdy bylo zahájeno vysílání z budovy vysílače v Brně-Komárově. Hudební program byl do vysílání zařazen od března následujícího 
roku a jako vedoucí hudebního oddělení povolán kapelník brněnského Národního divadla Jan Janota ${ }^{7}$. Od 1. října 1926 nastoupil do rozhlasu Haasův př́itel a spolužák z brněnské konzervatoře Břetislav Bakala. Působil zde zpočátku jako doprovazeč, komorní hráč a sólový pianista. Společně s Bakalou přišli do rozhlasu také další čtyři instrumentalisté: houslista Jindřich Polášek, violista Hynek Wolf a violoncellista Josef Křenek. Toto kvarteto, po několika málo měsících rozšîřené o dalších sedm členů, posléze vytvořilo základ budoucího brněnského rozhlasového orchestru. Úkol tohoto tělesa, jež bylo při skladbách s náročnějším obsazením rozšiřováno o dalších šest výpomocných hráčů, spočíval především v provozování salónní a zábavné hudby. Rozrůstání se tohoto tělesa, jež působilo pod Janotovým vedením, neproběhlo však v Brně tak razantně jako v Praze. A to i vzhledem k programovému zaměření brněnské rozhlasové stanice, které jí bylo svěřeno pražským vedením a jímž byla zejména péče o populární program. Co se týče hudební náplně rozhlasových relací brněnské stanice, byly např. v sezóně 1930/1931 vysílány zvláště přenosy operních představení a čtyři symfonické koncerty Zemského divadla, výjimečně koncerty Orchestrálního sdružení či Filharmonického sdružení Besedy brněnské a několik komorních koncertů z děl moravských soudobých skladatelů. Ostatní hudební pořady vážné hudby, včetně symfonických koncertů, byly přejímány z pražského rozhlasu. Nebylo tedy důvodů, aby byl brněnský rozhlasový orchestr významněji rozšiřován. ${ }^{8}$ Roku 1930 tak těleso čítalo 26 instrumentalistů.

Hudební programové směřování brněnské rozhlasové stanice začal od roku 1928 významně spoluutvářet muzikolog Karel Vetterl. Jeho tehdejší plány prozrazuje dopis adresovaný Vladimíru Helfertovi 1. srpna 1928, ${ }^{9}$ v němž Vetterl adresáta informuje, že vedoucí hudebního programu Janota nevykazuje ,žádný zájem o nějaké poctivé a promyšlené řešení v̌seobecné reformy programü“ a že ředitel brněnské stanice ing. Antonín Slavík Vetterla pověřil sestavením generálního programu pro následující sezónu. Svůj programový plán rozvrhl Vetterl do několika bodů:

I. přenosy symfonických koncertů brněnského Národního divadla, Orchestrálního sdružení, vokálních a komorních koncertů brněnské Filharmonické besedy a komorních koncertů Klubu moravských skladatelů

II. koncerty Radiojournalu

1) obligátní formy, jak dosud byly pěstovány

2) systematické koncerty historické se zvláštním zřetelem k moravikám

3) stylové koncerty novodobé hudby české a cizí, včetně hodinek věnovaných žijícím skladatelům a soustavného uvádění hudebních novinek

Jan Janota (1874-1957), šéfdirigent brněnského rozhlasového orchestru v letech 1925-1936.

8 Velký rozhlasový orchestr vznikl v Brně až roku 1938, kdy po okupaci československého pohraničního území byli do Brna přiděleni hráči z moravskoostravské, košické a částečně i bratislavské stanice.

9 Dopis uložen v Oddělení dějin hudby Moravského zemského muzea (ODH MZM), sign. A 2151. 
4) stylové koncerty se zřením k aktualitám a zvláště k české hudbě (k její účelné popularizaci v stylovém rámci)

5) literární hodinky s hudbou

6) hudební hádanky a soutěže o ceny

7) programy podle přání posluchačů mimo to kurz hudební výchovy probíhající od počátku sezóny do února

Jak je patrno z Vetterlova rozvržení, vystupoval orchestr brněnské rozhlasové stanice zejména $\mathrm{v}$ pořadech populární hudby, $\mathrm{v}$ nichž zaznívala jak posluchačsky př́stupnější díla klasické hudby, tak i směsi z operet a lehčí hudba. Účinkoval ovšem i v tzv. historických koncertech, které byly novinkou brněnského studia. Jednalo se o tematické pořady věnované hudbě 17.-18. století, v nichž byly hudební ukázky doprovázeny odborným výkladem. Společně s Vetterlem se na nich významně podílel zejména Vladimír Helfert, dále např. Jan Racek nebo Bohumír Štědroň. Od těchto relací byl již jen krůček ke vzniku specificky rozhlasové formy, jak si ji tehdy rozhlasoví teoretikové představovali. Historické koncerty se proměnily $\mathrm{v}$ historické obrazy, $\mathrm{v}$ montáže hudby, dialogů a biografických úryvků. Vznikla tak forma, která nebyla ani přednáškou, ani divadlem, ani koncertem, přitom však přístupnou a nenásilnou formou poskytovala poučení. Angažovanost brněnské stanice pro nové rozhlasové žánry kombinující funkci uměleckou a osvětovou se stala $v$ tomto období př́značnou. Zájmu brněnské stanice ovšem neunikl ani další dobový jev svázaný s rádiem, totiž hudba „šitá na míru“ rozhlasu. Dne 2. června 1931 uvedl místní rozhlasový orchestr pod taktovkou Břetislava Bakaly novinkový koncert rozhlasových skladeb soudobých moravských autorů. Vedle děl Vladimíra Ambrose a Osvalda Chlubny stála na programu i nová rozhlasová práce Pavla Haase. ${ }^{10}$

\section{Předehra pro rozhlas}

Haasova Předehra pro rozhlas, op. 11 byla svou formou, pojetím i zpracováním bezesporu nejosobitější skladbou zmíněného novinkového koncertu. A zároveň i skladbou, v níž se její autor pokusil vytěžit co nejvíce z možností, které poskytovala rozhlasová reprodukce. Postačí, srovnáme-li ji stručně se skladbami, jež stály v jejím sousedství: Vladimír Ambros vytvořil Episodu pro malý orchestr, jakousi krátkou náladovou hudební báseň se stručným programem, v němž se pokusil zachytit intimní svět posluchačů rádia mezi čtyřmi stěnami pokoje na městské periferii. Osvald Chlubna pak přispěl do programu Song Suitou pro malý orchestr se saxofonem, jejíž čtyři věty (I. Zpěv z ulice - fox tempo, II. Zpěv noci - tango tempo, III. Zpěv zatrpklý, IV. Zpěv válečný) ,,nemaji jiného úmyslu

10 Součástí koncertu byl i písňový cyklus skladatele Josefa Kohouta, který však pocházel z dř́vější doby a nebyl komponován se speciálním zřetelem k rozhlasovým. 
než pobaviti a upoutati posluchače spádem jazzových rytmů, divokostí souzvukovou a trochu i náladou". ${ }^{11}$

V Předehře pro rozhlas spojil Pavel Haas síly se svým bratrem Hugem, autorem veršovaného textu, a společně vytvořili krátké dílko určené malému orchestru a mužskému vokálnímu kvartetu, jehož členům je zároveň svěřena role recitátorů. Kompozice je apoteózou rozhlasu a jeho vynálezce Marconiho a vyjadřuje dle slov skladatele samotného, ,jásavý obdiv nad novým vitězstvím lidského mozku - nad odhalením jednoho z nesčetných tajemství jediného zázraku všeho byti - - Boži prírody!"12 Za organizací novinkového koncertu stála zvláště iniciativa Karla Vetterla, který se o tehdy moderní rozhlasovou hudbu zasazoval a o této problematice publikoval dokonce několik statí na stránkách hudebního časopisu Tempo - Listy Hudebni matice. ${ }^{13}$ Kvůli pohnutým osudům Pavla Haase v době okupace ČSR a 2. světové války se nedochovala žádná korespondence, která by dokládala, kdy a kým byl Haas z rozhlasu osloven. Patrně šlo o př́mou zakázku rozhlasu a předem vybraní autoři byli osloveni bezprostředně. Ambros, Chlubna i Haas byli Janáčkovými žáky a byli organizování v Klubu moravských skladatelů. Je pravděpodobné, že při výběru skladatelských osobností měl jisté slovo Břetislav Bakala, jenž byl rovněž členem Klubu ${ }^{14}$ a udržoval zvláště s Haasem a Ambrosem prátelské styky. Vladimír Ambros a Osvald Chlubna čerpali ve své tvorbě inspiraci zvláště $\mathrm{z}$ francouzskho impresionismu, avšak do jejich děl pronikaly i prvky tehdy módního konstruktivismu. Osobnost Pavla Haase se naopak profilovala na veřejnosti orientací vyhraněně moderní až avantgardní, ačkoli jeho komorní díla s sebou nezř́ídka ještě nesla zbytky romantického gesta, projevujícího se intimní citovostí a vnášením mimohudebního obsahu. Haasův II. smyčcový kvartet „Z opičich hor “ premiérovaný v Brně roku 1926 ukazuje skladatelovu bohatou a pestrou práci s rytmikou po vzoru Stravinského, ve druhé větě připomene zvuková ilustrace rozjíždějícího se koňského povozu konstruktivismus Honeggerova světoznámého Pacificu 231, závěr díla pak přináší jazzové synkopované taneční rytmy, podpořené dokonce bicí soupravou. Své úsilí o soudobou, moderní hudební řeč a výraz Haas přesvědčivě formuloval v rozhovoru pro Moravské noviny roku 1933:

„Pravé umění neztrácí nikdy svého poměru k životu. Jest idealisovaným obrazem života. Hledá své podněty a inspirace v současném životě. Nemůže proto být pravá hudba věku letadel, ponorek a rozhlasu totožná s hudbou doby dostavniků a plachetnic. Je-li člověk ve svých názorech, svým chováním a způsobem života ditětem své doby, pak nesmí ve svých názorech na uměni zůstávati o sto let poza-

11 K. V. [= Vetterl; Karel]. Novinky v rozhlasové hudbě. Radiojournal 9, 1931, č. 22, s. 3.

12 Ibid, s. 3.

13 VETTERL, Karel. O novou hudbu pro rozhlas. Tempo - Listy Hudebni matice 8, 1928/1929, č. 10, s. 327-330. VETTERL, Karel. Rozhlasová hudba. Tempo - Listy Hudební matice 9, 1929/1930, č. 2, s. 53-57, č. 3, s. 94-98.

14 Členem Klubu moravskch skladatelů byl mj. i Karel Vetterl. 
du. [...] Milujeme telefon, bezdrátovou telegrafii, rozhlas, zvukový film... Musíme být prístupni modernímu uméni. "'15

Předehru pro rozhlas komponoval Pavel Haas dle autografního záznamu v čistopise partitury ${ }^{16}$ od 26. zář́ 1930. Dochovaná tužková skica díla však nese počáteční datum 20. ř́jina $1930 \mathrm{~s}$ datem dokončení v březnu $1931 .{ }^{17}$ Skica je zaznamenána formou particellu a dle Haasových četných poznámek v ní se lze domnívat, že největším oříškem pro skladatele byla instrumentace. Aby dílo dobře vyznělo při přenosu s rozhlasového studia, bylo nutno důkladně řešit výběr nástrojů, rozvážit jejich vzájemné kombinace a užití určitých nástrojových poloh. Poprvé zde Haas psal pro saxofon, jehož rozsah a ladění si do skici dưrazně poznamenal. V době, kdy Pavel Haas svou Předehru komponoval, mohl se již v tomto ohledu poučit na řadě rozhlasových skladeb, jež ve valné většině pocházely z pera soudobých německých autorů. Jistě mohl těžit i ze zkušeností a praktických rad př́tele Břetislava Bakaly. V Berlíně bylo tou dobou už zř́zeno pokusné oddělení pro hudbu v rozhlase při Státní vysoké hudební škole (Staatliche Hochschule für Musik und darstellende Kunst), kde byly rozhlasem konány pokusy s různými druhy nástrojů, byly srovnávány polohy a instrumentační shluky. Otázce instrumentace a interpretace hudby v rozhlase bylo dokonce věnováno i několik německojazyčných studií. Na stránkách časopisu Pult und Taktstock uveřejnil roku 1927 svou stat' Die Klangfarben der Orchesterinstrumenten und Singstimmen im Rundfunk Hermann Ambrosius, ${ }^{18}$ německý skladatel, který od roku 1925 působil jako zvukový a hudební režisér Středoněmeckého rozhlasu v Lipsku (Die Mitteldeutsche Rundfunk AG). Na jeho práci navázal dirigent lipského rozhlasového orchestru Alfred Szendrei, jehož př́ednáška Der Klang der Orchesterinstrumente im Rundfunk, proslovená na kongresu o rozhlasové hudbě v Göttingenu roku 1928, byla ve zkrácené verzi otištěna v časopise Pult und Taktstock ${ }^{19}$ a roku 1931 také v československém německém hudebním časopise Der Auftakt. ${ }^{20}$ Ze Szendreiových závěrů čerpal v citované studii O novou hudbu pro rozhlas i Karel Vetterl.

15 HAAS, Pavel. O moderní hudbě. Moravské noviny, 23. 10. 1933.

16 ODH MZM, sign. A 22.693a.

17 ODH MZM, sign. A 22.693c.

18 AMBROSIUS, Hermann. Die Klangfarben der Orchesterinstrumenten und Singstimmen im Rundfunk. Pult und Taktstock. Fachzeitschrift für Dirigenten 4, 1927, č. 7-8, s. 95-100.

19 SZENDREI, Alfred. Der Klang der Orchesterinstrumente im Rundfunk. (Aus einem Vortrag, gehalten anlässlich der Tagung für Rundfunkmusik in Göttingen). Pult und Taktstock. Fachzeitschrift für Dirigenten 5, 1928, č. 7, s. 71-75.

20 SZENDREI, Alfred. Der Klang der Orchesterinstrumente im Rundfunk. Der Auftakt 11, 1931, č. 8-9, s. 203-206. 


\section{Rozhlasová instrumentace}

Szendrei pojednává postupně o jednotlivých nástrojových skupinách a vyslovuje se o problémech, s nimiž se může potýkat dirigent a režisér při jejich snímání skrze mikrofon a přenášení do rozhlasového éteru. Stručně zde budeme formulovat Szendreiovy poznatky, které jsou důležité pro poznání dobové rozhlasové interpretační praxe: Szendrei konstatuje, že dřevěné dechové nástroje dosahují při přenosu nejlepších výsledků a až na nejvyšší tóny flétny působí z reproduktoru věrným zvukovým dojmem. Velmi přirozeně podle něj znějí i trubky a pozouny, které v začátcích rozhlasové praxe naopak působily dirigentovi většinou spíše starosti. Doporučuje však obezřetné zacházení s jejich dynamikou, kdy i ve forte je nutno dbát na měkký zvuk těchto nástrojů. Za velmi problematický považuje kvartet lesních rohů, při jehož uplatnění, zvláště je-li veden ve wagnerovsko-straussovské polyfonní sazbě, mohou vznikat tzv. sumační tóny. U kontrabasů je podle Szendreie hlavním úkolem při rozhlasové reprodukci zajistit jejich výhodné postavení vzhledem ke zvukovému snímači, prričemž vychází ze zkušenosti, že tehdejší mikrofony špatně reagovaly na nízké frekvence. K zesílení basů nedoporučuje ani kontrafagot, při jehož použití vznikají ruchy, ani basovou tubu, která je zase nástrojem př́liš hřmotným. Ostatní smyčcové nástroje (housle, violy, violoncella) znějí podle autora článku přses mikrofon poměrně dobře, avšak je důležité zvážit četnost jejich obsazení vzhledem ke skladbě a prostoru, z něhož se vysílá. Také harfa, celesta, kytary, mandoliny a rovněž bicí nástroje s určitou výškou tónu (zvonkohra, xylofon) si podržují v rozhlase svůj přirozený zvuk. Naopak tympány (zejména při víréení) a bubny působí v silné dynamice a při užití jejich většího počtu velice rušivě. U klavíru znějí výborně pasáže a běhy, zkreslení nastává zejména v pomalém tempu při nadměrném užití pedalizace.

Na základě uvedeného můžeme tedy resumovat, že nejdůležitějšími rysy pro dobré vyznění rozhlasové instrumentace byla „,svítivost“ vrchních hlasů, průzračnost basů, péče o zachování individuálních zvukových barev tak, aby jednotlivé nástroje vynikly, jejich zvuk se vzájemně nepřekrýval a nesléval dohromady. Zkoumáme-li Haasovu Předehru pro rozhlas, můžeme pozorovat, že její autor si byl těchto zásad dobře vědom a pokusil se je ve své práci zohlednit. Předehra využívá následujícího orchestrálního obsazení: flétna (pikola), hoboj, klarinet in $\mathrm{B}$, fagot, 2 lesní rohy in F, altový saxofon in Es, 2 trubky in F, trombón, suzafon, velký buben, činely, triangl, malý buben, zvonkohra, zvony, tam-tam, harfa, klavír a smyčce. V celkovém vyznění orchestrální složky převládají v Předehře $\mathrm{u}$ všech nástrojů vyšší polohy. Basy jsou využívány dosti úsporně a v dynamických vrcholech Haas bud' kombinuje kontrabasy se suzafonem, nebo využívá samotného suzafonu, eventuálně trombónu. Znatelná je v celé skladbě především Haasova snaha vyzdvihnout polohově i charakterově hlavní témata tak, aby se odlišovala a neztratila se $\mathrm{v}$ doprovodu. Témata jsou většinou svěrena sólovým dechovým nástrojům, př́ípadně houslím a violoncellům. Proti zpěvným hudebním myšlenkám Haas staví figurativní staccatový doprovod. V něm využívá mj. klavíru, který je traktován bez pedálu a v jeho doprovodných partiích se převážně 
stř́dají rozložené akordy se staccatovými úhozy. Rozsáhlá sestava bicích nástrojů na první pohled překvapí, Haas s ní pracuje ovšem velice stř́idmě. Nepřipisuje bicím výraznější samostatnou úlohu, spíše se jejich prostřednictvím pokouší barevně celou partituru ozvláštnit. Zejména zvonky a triangl podporují lehký, radostný a prosvětlený charakter díla. ${ }^{21}$

Vokální (pěvecká a recitační) složka Haasovy Předehry je svěřena mužskému kvartetu ( 2 tenory, 2 basy). Každý z jeho jednotlivých členů mluveným projevem postupně přednáśí jednu ze slok veršovaného textu. I zde šlo skladateli o výrazné vzájemné odlišení témbru mužských hlasů, k čemuž využil stř̌́dání různých hlasových oborů: postupně následují I. tenor, II. bas, II. tenor a I. bas. Ke společnému homofonnímu zpěvu slavnostního chorálového ražení se všechny čtyři hlasy spojují v páté sloce.

\section{Předehra pro rozhlas, op. 11 - text Hugo Haas}

1.

Jsem zvuk!

$\mathrm{V}$ touze náplně, tančím a zpívám a houpám se na vlně. Pro velkou myšlenku jdu s tajemstvím do války, jsem zvuk a zvučím a toužím do dálky...

2.

Jsem vlna...

sférickým řevem

a poruchami

od bursovních zpráv

až „páni a dámy“

po „dobrou noc“"

nesu zvuk! Záplavy tónů

chrlím do mikrofonu...

3.

Jsem mikrofon!

Citlivý jak lidská duše,

hluše a suše

vnímám a hltám zvukové vlny, cévy mé jsou jich plny

21 V Haasově skice Předehry můžeme ostatně najít poznámku: „při nastoupení každého hlasu (jako by se světlo rozsvitilo) lesklé zazvoněni" (ODH MZM, sign. A 22.693c). 
až k prasknutí.

Hledáme cestu k lidskému sluchu, voláme slávu lidskému duchu

a hledáme amplion...

4.

Jsem amplion!

Nesu v svých útrobách

zvuk, vlny a mikrofon

a lidská ruka dvěma prsty

mou vůli hubíc,

mé útroby rozdává

milionům eustachových trubic

a řídí mou sílu;

jsem tlumočník světa dílů...

5.

Jsme velká čtyřdohoda,

když sever s jihem

a západ s východem

ruku si podá, hned

objímáme celý svět.

Celého světa tóny znějí:

Marconi, Marconi!

\section{Estetika rozhlasové hudby}

Dobový diskurs o rozhlasové hudbě se však nevyčerpával řešením technických problémů. Někteří soudobí skladatelé a teoretikové se pokoušeli nalézt v rozhlasu nové výrazové formy a nový rozhlasový sloh. Rozhlas byl chápán jako samostatný obor umělecké činnosti vyznačující se vlastní osobitou estetikou. V hudební oblasti se ke konci 20. let přihlásila ke slovu řada propagátorů nového hudebního rozhlasového stylu, přibývali však i jeho odpưrci. Přibližně v polovině 30 . let již však bylo zřejmé, že se jednalo o přechodnou dobovou záležitost, která postupně vymizí. ${ }^{22}$ Představy o tom, jak má nová rozhlasová hudba a její estetika vypadat, byly nejrůznější.

22 V českém prostředí se proti principu rozhlasovosti vyslovil Bernard Kosiner, meziválečný rozhlasový kritik a teoretik. V jedné ze svých úvah psaných pro Lidové noviny roku 1933 podrobil požadavek zvláštní rozhlasové estetiky př́sné kritice: „,hledá se samostatná, zvláštni estetika rozhlasu, jako by pro rozhlas - pokud je v něm umění - měl platit jiný estetický rád než pro hudbu nebo pro poesii. [...] Protože literaturu i drama bylo nutno pro rozhlas přizpuisobit, domnivaji se někteři, že literární a dramatické hodnoty v rozhlase neplatí. Proto často vidime, že logičnost v rozhlase je jiná (pravidelně horší), že myšlenka je prostší, chudší, 
V raném stupni rozhlasového vývoje roku 1925 uveřejnil své myšlenky skladatel Kurt Weill, který tehdy působil jako hudební referent časopisu Der Deutsche Rundfunk. V článku Möglichkeiten absoluter Radiokunst ${ }^{23}$ vytýká rozhlasu, jenž byl doposud chápán jako prostředek zábavy a poučení zprostředkovávající veřejnosti mistrovská díla hudby a literatury, že z uměleckého hlediska jsou výsledky jeho činnosti spíše kvantitativní než kvalitativní. Weill se při svém načrtávání uměleckých možností skrývajících se v novém vynálezu nechal inspirovat tzv. absolutním filmem. Tento filmový žánr se na počátku 20. let prosazoval v Německu v tvorbě režisérů Waltera Ruttmana, Hanse Richtera ad. Filmové snímky ukazovaly animace abstraktních objektů, linií, forem a světelných tónů. Weillova idea absolutní rozhlasové hudby, jakési abstraktní hry hudby a zvuků, se blížila dnešnímu „soundartu“. Je to ostatně zřejmé z jeho slov: „Nun können wir uns sehr gut vorstellen, daß zu den Tönen und Rhythmen der Musik neue Klänge hinzutreten würden, Klänge aus anderen Spähren: Rufe menschlicher und tierischer Stimmen, Naturstimmen, Rauschen von Winden, Wasser, Bäumen und dann ein Heer neuer, unerhörter Geräusche, die das Mikrophon auf künstlichem Wege erzeugen könnte, wenn Klangwellen erhöt oder vertieft, übereinandergeschichtet oder ineinanderverwoben, verweht und neugeboren werden würden. Um das Wichtigste nochmals zu betonen: Ein solches Opus dürfte kein Stimmungsbild ergeben. keine Natursinfonie mit möglichst realistischer Ausnutzung aller vorhandenen Mittel, sondern ein absolutes, über der Erde schwebendes, seelenhaftes Kunstwerk mit keinem anderen Endziel als dem jeder wahren Kunst: Schönheit zu geben und durch Schönheit den Menschen gut zu machen und gleichgültig gegen die Kleinlichkeiten des Lebens. Ob all das Utopie bleiben wird, hängt von der Fortschritten der Technik ab. " ${ }^{24} \mathrm{Na}$ svou dobu prŕliš radikální Weillovy představy absolutní rozhlasové hudby nenašly širšího ohlasu a ani sám Weill se neodhodlal vytvořit dílo podobného druhu.

Další podněty poskytl rozvoji rozhlasové hudby roku 1928 kongres v německém Göttingenu, který se cele zaměřoval na tuto problematiku. V úvodní přednášce nastínil svůj názor plodný autor rozhlasových kompozic a pedagog experimentálního oddělení pro rozhlasovou hudbu na Vysoké hudební škole v Berlíně, skladatel Max Butting. Ten př́sně odlišil „rozhlasovou hudbu“, která se obrací pouze ke sluchovému smyslu radioposluchačů, od „hudby v rozhlase“. Za nevhodnou k rozhlasovému vysílání považoval každou romanticko-expresivní hudbu, která dle Buttinga vyžaduje smyslovou blízkost interpretů. Naopak jako nejvhodnější pro rozhlasové vysílání se mu jevila hudba odpoutaná od vztahu k osobnosti

nevýznamná, že dramatičnost v rozhlase je na nižši úrovni než v divadle, že i poesie je v něm méně poetická." Viz KOSINER, B. Mluvené slovo. Lidové noviny 41, 15. 4. 1933, č. 193, s. 11.

WEILL, Kurt. Möglichkeiten absoluter Radiokunst. Der Deutsche Rundfunk 3, 1925, č. 26, s. 1625-1628. Citováno dle: WEILL, Kurt. Musik und Musikalisches Theater: Gesammelte Schriften. Mainz: Schott Musik International, 2000, s. 264-270.

Ibid., s. 269. 
reprodukčního umělce. Pravou rozhlasovou hudbu je proto třeba vytvářet tak, aby podléhala logice čistého slyšení. ${ }^{25}$

Vedoucí hudebního oddělení brněnského rozhlasu Karel Vetterl dospěl ve svém článku o rozhlasové hudbě ${ }^{26} \mathrm{k}$ podobným závěrům jako Butting. Ve svém náhledu na tuto problematiku vychází z habilitační přednášky německého muzikologa Heinricha Besselera Grundfragen des musikalischen Hörens (1925). Besseler v ní zavádí pojem Gebrauchsmusik, jímž označuje hudbu užitkovou (z dnešního pohledu hudbu nonartificiální), tedy hudbu, která nevystupuje čistě jako estetický objekt, nýbrž naplňuje určitou sociální funkci (např. hudba taneční, liturgická, pracovní písně atd.). Podle Vetterla je v rozhlase potřeba „nového hudebního slohu, který se uchyluje k prostotě výrazu, priozračnosti formové a hravé reproduk$c i “{ }^{i “}{ }^{27}$ což odůvodňuje změnou mentality obecenstva a novým kulturním rozvrstvením společnosti, žádající si nejvíce hudbu zábavnou. Hlavní zdroj zmíněných myšlenek spočíval v reakci na subjektivismus pozdního romantismu a expresionismu, která se v Německu šírilla pod heslem tzv. nové věcnosti (Neue Sachlichkeit). V jejím duchu byla hlásána nutnost vyslovit uměním všední životní pocity, které jsou společné širokému lidskému kolektivu, zdůrazňována neokázalost a antiiluzivnost projevu. ${ }^{28}$

V oblasti čistě instrumentálních rozhlasových skladeb byly v hledáčku skladatelů především orchestrální suity, které často těžily z jazzu a dobové populární hudby. Na této bázi spočívá mj. zmíněná Song Suita Osvalda Chlubny. Posluchače se snažily oslovovat svou myšlenkovou nenáročností, taneční hravostí a pestrostí danou různorodým charakterem jednotlivých vět. Větší rozmaninost vykazovaly formy vokální, v nichž často docházelo ke vzájemné kombinaci forem hudebních a literárních. Pro řadu děl se stalo př́značné zapojení recitátora či hlasatele. V mezinárodním kontextu měl význam zejména rozhlasový experiment skladatelů Kurta Weilla a Paula Hindemitha Der Lindberghflug (Lindberghiov let), na němž spolupracovali se spisovatelem a dramatikem Bertoltem Brechtem. Dílo vzbudilo živý ohlas při svém provedení na Festivalu komorní hudby v Baden-Badenu roku 1929, kde zaznělo pod taktovkou Hermanna Scherchena. Dějem skladby je prostá, přitom však významná a pro většinu zajímavá událost: prrelet Atlantského oceánu Američanem Charlesem Lindberghem. Jde o hudební rozhlasové drama, Radiolehrstück, který se svými prvky přibližuje rozhlasové reportáži či rozhlasovému hlášení denních zpráv. Dílo je složeno ze 16 krátkých částí, v nichž se střídá hlasatel se zpěvy (sbory, recitativy, ariosními částmi, dialogy). V jednom ze svých výstupů např. podává Lindbergh posluchačům seznam věcí potřebných pro náročný let: „2 elektrische Lampen, 1 Rolle Seil, 1 Rolle

25 GUTMAN, Hanns. Rundfunk-Musik: Kongreß in Göttingen. Der Auftakt 8, 1928, č. 5-6, s. $125-129$.

26 VETTERL, Karel. Rozhlasová hudba. Tempo - Listy Hudební matice 9, 1929/1930, č. 2, s. 53-57, č. 3, s. 94-98.

27 Ibid., s. 56.

28 V oblasti dramatu bylo na těchto principech založeno tzv. epické divadlo Bertolta Brechta. 
Bindfaden, 1 Jagdmesser" atd. Následuje alegorické vylíčení Lindberghových protivníků, mlhy, sněhové bouře a spánku, obohacené mimohudební zvuky. Součástí intimního dialogu Lindbergha s motorem letadla je autentický zvuk motoru a při konečném Lindberghově přistání na francouzské letiště Le Bourget je posluchačům reprodukováno nadšení tehdejších diváků z originální gramofonové desky. Ne náhodou se československá premiéra Lindberghova letu uskutečnila v brněnském rozhlase 7. ledna 1931 pod taktovkou Břetislava Bakaly. To už byl ovšem Haas v plném proudu práce na své Předehře pro rozhlas.

Pokusíme-li se v závěru srovnat jednotlivé skladby brněnského novinkového koncertu rozhlasové hudby 2. června 1931, dospějeme k závěru, že každá $\mathrm{z}$ nich reprezentuje určitou stylovou tendenci: Episodu Vladimíra Ambrose můžeme chápat jako programní skladbu, která se pokouší vyprovokovat subjektivní zážitek posluchače paralelou mezi náladou hudby a atmosférou, kterou prožívá posluchač osamocen u rádiového aparátu. Song Suita Osvalda Chlubny se svým tanečním charakterem nejvíce blíží Besselerově Gebrauchsmusik, ačkoli ani ona se nezř́ká konkrétní programové náladovosti. Haasova Předehra pak nejvíce souzní s nesubjektivním, věcným slohem, v němž je zvukový materiál formován tak, aby hudba „odpovídala svou stylovou pregnancí nadosobním vlastnostem rozhlasu“ “. ${ }^{29} \mathrm{~S}$ tím koresponduje námět: apoteóza rozhlasu, vyjádřená personifikovanými součástmi rádiového přenosu: zvukem, vlnou, mikrofonem a amplionem. Hudebně oproštěné zpracování pak využívá motorických rytmů, názvuků taneční hudby, není expresivně vyhrocené, naopak se jedná o pozvolnou gradaci směřující k oslavnému závěru.

Ondřej Pivoda (pivoda@mail.muni.cz), Ústav hudební vědy, Filozofická fakulta, Masarykova univerzita; Oddělení dějin hudby, Moravské zemské muzeum, Brno, CZ.

\section{ABSTRACT RADIO MUSIC AND PAVEL HAAS}

A genesis of Pavel Haas' Radio Ouverture, op. 11 composed between 1930/1931 is connected with a development of radio broadcasting from 1920's. Haas' Ouverture is explored in context of specific technical conditions, influencing music interpretation in radio broadcast at that time (especially a quality of microphones, acoustic conditions of broadcast studios, a size and instrumentation of radio orchestras) and in context of period aesthetic criterions of radio music production (Weill's absolute Rundfunkmusik, Besseler's Gebrauchsmusik, new objectivity etc.). This aspects affected substantially a final shape of Haas' work concerning its orchestration, musical form and style.

\section{Key words}

Pavel Haas, radio music, radio, Kurt Weill, Max Butting, Karel Vetterl, Gebrauchsmusik, new objectivity

29 VETTERL, Karel. Rozhlasová hudba. Tempo - Listy Hudební matice 9, 1929/1930, č. 2, s. 57. 


\section{Bibliography}

AMBROSIUS, Hermann. Die Klangfarben der Orchesterinstrumenten und Singstimmen im Rundfunk. Pult und Taktstock. Fachzeitschrift für Dirigenten 4, 1927, č. 7-8, s. 95-100.

BUKOFZER, Manfred. Rundfunk-Instrumentation? Melos. Zeitschrift für Musik 10, 1931, č. 2, s. $58-60$.

BUTTING, Max. Der Komponist über Rundfunkmusik. Die Musikblätter des Anbruch 11, 1929, č. 2 , s. $86-87$.

GUTMAN, Hanns. Runfunk-Musik: Kongreß in Göttingen. Der Auftakt 8, 1928, č. 5-6, s. 125-129.

HAILEY, Christopher. Rethinking Sound: Music and Radio in Weimar Germany. In Music and Performance in Weimar Republic (ed. Brian Gilliam). Cambridge: Cambridge University Press, 1994. s. 13-36.

HEINSHEIMER, H. Lindberghův let. Radiojournal 9, 1931, č. 1, s. 4.

KOSINER, B. Mluvené slovo. Lidové noviny 41, 15. 4. 1933, č. 193, s. 11.

LATZKO, Ernst. Rundfunk-Probleme. Pult und Taktstock. Fachzeitschrift für Dirigenten 4, 1927, č. 7-8, s. 85-91.

LATZKO, Ernst. Rundfunk und öffentliche Musikpflege. Der Auftakt 9, 1929, č. 7-8, s. 161-163.

MERSMANN, Hans - SCHULTZE-RITTER, Hans - STROBEL, Heinrich. Neue Rundfunkmusik. Melos. Zeitschrift für Musik 8, 1929, č. 7, s. 319-321.

NICK, Edmund. Neue und alte Rundfunkmusik. Der Auftakt 10, 1930, č. 3, s. 78-80.

PATZAKOVÁ, A. J. (ed.). Prvních deset let Československého rozhlasu. Praha: Nákladem Radiojournalu, Čsl. zpravodajství radiotelefonického, 1935. 1039 s.

PEDUZZI, Lubomír. Pavel Haas. Život a dílo skladatele. Brno: Muzejní a vlastivědná společnost, 1993. $175 \mathrm{~s}$.

PIVODA, Ondřej. Pavel Haas. Janáčkiov nejnadanějši žák. Brno: Moravské zemské muzeum, 2014. $43 \mathrm{~s}$.

RÝPAR, Vl. Možnosti rozhlasu. Index. Leták kulturní informace 2, 1930, č. 3, s. 21-22.

SACHS, Kurt. Rundfunk und Konzertsaal. Die Musikblätter des Anbruch 11, 1929, č. 5, s. 217-218.

SCHEINBERG, Erica Jill. Music and the Technological Imagination in the Weimar Republic: Media, Machines and New Objectivity. Dizertace. University of California, Los Angeles, 2007.

SCHOEN, Ernst. Die Rundfunkkompositionen für Baden-Baden. Melos. Zeitschrift für Musik 8, 1929, č. 7, s. 313-315.

STEINHARD, Erich. Tonfilme, Liebhaberkunst, Rundfunkmusik in Baden-Baden. Der Auftakt 9 , 1929 , č. 9, s. 215-217.

SZENDREI, Alfred. Tonkünstler und Rundfunk. Pult und Taktstock. Fachzeitschrift für Dirigenten 4, 1927, č. 7-8, s. 77-84.

SZENDREI, Alfred. Der Klang der Orchesterinstrumente im Rundfunk. (Aus einem Vortrag, gehalten anlässlich der Tagung für Rundfunkmusik in Göttingen). Pult und Taktstock. Fachzeitschrift für Dirigenten 5, 1928, č. 7, s. 71-75.

SZENDREI, Alfred. Die Stimme im Rundfunk. Die Musikblätter des Anbruch 10, 1928, č. 9-10, s. 376-383.

SZENDREI, Alfred. Der Klang der Orchesterinstrumente im Rundfunk. Der Auftakt 11, 1931, č. 8-9, s. 203-206.

K. V. [= Vetterl; Karel]. Novinky v rozhlasové hudbě. Radiojournal 9, 1931, č. 22, s. 3.

VETTERL, Karel. O novou hudbu pro rozhlas. Tempo - Listy Hudebni matice 8, 1928/1929, č. 10, s. $327-330$.

VETTERL, Karel. Rozhlasová hudba. Tempo - Listy Hudebni matice 9, 1929/1930, č. 2, s. 53-57, č. 3, s. 94-98.

WARSCHAUER, Frank. Die Musik im Rundfunk. Die Musikblätter des Anbruch 8, 1926, Sonderheft Musik und Maschine, s. 374-379. 
WARSCHAUER, Frank. Die Göttinger Tagung für Rundfunkmusik. Pult und Taktstock. Fachzeitschrift für Dirigenten 5, 1928, č. 5-6, s. 58-59; též Die Musikblätter des Anbruch 10, 1928, č. 6, s. 212-215.

WARSCHAUER, Frank. Rundfunkmusik. Die Musikblätter des Anbruch 11, 1929, č. 2, s. 84-86.

WIENER, Karl. Der Einfluss des Rundfunks auf die musikalische Form. Pult und Taktstock 7 , 1930 , č. 2 , s. $28-30$. 
